\title{
Popularity and usage of different skincare agents among the inhabitants of Galle district in Southern province, Sri Lanka
}

\author{
Mayuri Napagoda*, Buddhika Dahanayake, Shyama Lankika, Gayani Dahanayake, \\ Mahesh Wannakukorala, Ravindi Manampery, Nadeesha Jayasekera, Thilani Tiranagama and \\ Dinushi Kumari
}

Faculty of Medicine, University of Ruhuna, 80000, Galle, Sri Lanka

*Correspondence: mayurinapagoda@yahoo.com; (D) https://orcid.org/0000-0003-4617-990X

Received: $27^{\text {th }}$ July 2019, Revised: $19^{\text {th }}$ May 2020, Accepted: 02 ${ }^{\text {nd }}$ June 2020

\begin{abstract}
Cosmetics could be considered as one of the essential commodities in modern society, and the use of skincare agents has become a common practice in both men and women in Sri Lanka. Therefore, the present study was conducted to determine the popularity and usage of skincare agents among inhabitants in Galle district, Sri Lanka, and to assess the knowledge, attitudes, and awareness on the use of those products. Further, the attempts were made to identify widely used home-made natural skincare preparations for future pharmacological, clinical, and phytochemical evaluations. Thus, 390 participants were recruited to the study by random sampling method and semi-structured, and open-ended interviews were conducted using a pre-validated questionnaire. Total number of users of skincare products were found to be 207 (53.1\%). Skincare products were highly popular among females while unmarried people and the people of the age group 18-30 years were reported to be regular users. Although the usage of synthetic skincare products was more prevalent than herbal preparations, the knowledge on different parameters of the synthetic products was not satisfactory as only $100(48.3 \%), 48(23.2 \%)$ and $82(39.6 \%)$ individuals among the regular users were aware of $\mathrm{pH}$, sun protection factor (SPF) and chemical composition of those products respectively. Interestingly, most of the participants believe in the safety and non-toxic features of natural herbal formulations, thus, it reflects the urgent need of exploring Sri Lankan flora for the development of herbal cosmetics.
\end{abstract}

Keywords: Herbal preparations, skincare agents, synthetic cosmetics

\section{Introduction}

The usage of cosmetics dates back to the time of ancient civilizations where different types of natural materials had been used to improve the appearance of the skin. For instance, the use of kohl by ancient Egyptian women to darken their eyelids and the use of poisonous carbonate by Greek women to achieve a pale complexion (Ribeiro et 
al. 2015). In modern days, cosmetics are essential commodities of life and as a result, a wide variety of products have been developed and marketed. Cosmetic preparations are widely popular in any society among both females and males in order to achieve skincare, cleaning, and to enhance the appearance (Mahé et al. 1993). Skincare products are the medicinal preparations that manifest beneficial topical actions and provide protection against degenerative skin conditions. The beneficial effects include the improvement of skin tone, texture, and radiance while reducing the wrinkles (Ribeiro et al. 2015). With increased awareness of the negative side effects of chemicals used in preparation of cosmetics, there has been an increasing demand for natural cosmetic products that are mainly based on traditional herbal preparations for skincare (Rekha et al. 2015, Ahmad et al. 2008).

Sri Lanka has a rich history of ethnopharmacological practices passed on from generation to generation for thousands of years. Many plant species have been utilized in traditional medicine to improve complexion and to treat various dermatological conditions (Jayaweera 1982, Wijesundera 2004). Especially in the Ayurveda system, herbal preparations have been documented for conditions such as acne, dark patches, hyperpigmentation, wrinkling, dehydrating skin, and aging of the skin. A recent study has pointed out 35 Ayurvedic formulas for increasing the fairness of facial skin and 12 formulas for acne in which Lodhra (Symplocos racemosa) was the most prominent constituent (Gunapala and Kumara 2015). Over the years, some of these herbal preparations were developed and marketed as natural skincare agents. However, there are no reports on studies carried out neither to assess the popularity of the herbal skincare preparations nor to evaluate the usage and efficacy of synthetic skincare agents among Sri Lankans. Therefore, the present study was carried out to assess the popularity and usage of skincare agents among the inhabitants in Galle District, Sri Lanka. Further, a special emphasis was given to evaluate their knowledge and awareness on different parameters in the synthetic products, side effects associated with the usage as well as their attitudes on the efficacy of those products. In addition, attempts were made to identify widely used home-made natural skincare preparations in the community, for future pharmacological, clinical, and phytochemical evaluations.

\section{Material and Methods}

\subsection{Study area}

Galle is one of the 25 administrative districts in Sri Lanka and lies in the Southern Province of the country. The total area of $1,652 \mathrm{~km}^{2}$ is further divided into 19 divisional secretariats divisions and the population is 1,063,334 [www.statistics.gov.lk]. The weather in Galle is hot and humid all year round. The driest period of the year (from December to March), is accompanied by 7-8 hours of sunshine each day. The average monthly solar radiation was reported in the range of $17.76-23.32 \mathrm{MJ} / \mathrm{m}^{2}$ for the period of October 2014 to May 2015 (Pers. Comm, Department of Meteorology). The high solar radiation received by the study area makes the people extremely vulnerable to 
dermatological conditions caused by excessive exposure to solar radiation, thus it is possible to hypothesize that skincare agents are widely popular in this community.

\subsection{Data collection and analysis}

Information was documented from residents of all nineteen secretariat divisions in Galle district. This survey was carried out from September 2015 to May 2017 and the data were collected through semi-structured and open-ended interviews using a prevalidated questionnaire. Twenty-five undergraduates/ pre-intern doctors were employed for the pre-validation of the questionnaire designed for the study. The random sampling method was used to recruit 390 volunteers from the district and prior informant's consent was obtained in writing. The number of participants to be taken from each divisional secretariat was based on the proportion of the population of the particular area. Visits were made to randomly selected households in each divisional secretariat area and the data were collected from people who have been living in Galle district for the past five years, above 18 years of age, and expressed their willingness to participate in this study. The minimum sample size for this study was determined based on the equation given below.

$$
\mathrm{N}=\mathrm{Z}^{2} \mathrm{P}(1-\mathrm{P}) / \mathrm{d}^{2}
$$

where $\quad \begin{aligned} & \mathrm{Z}=1.96 \text { for } 95 \% \text { confidence } \\ & \mathrm{N}=\text { minimum sample size } \\ & \mathrm{P}=\text { estimated proportion in study population } \\ & \mathrm{d}=\text { desired absolute precision }\end{aligned}$

Since there were no reported studies from this area, the estimated proportion is considered as $50 \%$, and therefore minimum required sample size was 384 .

Ethical approval was obtained from the ethical review committee, Faculty of Medicine, University of Ruhuna, Sri Lanka (permit issued on 15/09/2015). Data were analyzed by SPSS statistical package-version 20 using descriptive statistics. A Chisquare test was used to determine the correlation between the socio-demographic data and the usage of skincare agents.

\section{Results}

The study population of 390 individuals (males: 182, females: 208) comprised of people of different age categories above 18 years, marital status, level of formal education, and financial status. Among those, the majority were in the age group of 18-30 years (174 individuals), unmarried (172 individuals), with formal education up to university entrance examination (158 individuals). Most of the people in the study population earned between Rs. 2,000 to 20,000 (134 individuals) per month while the others with a monthly income between Rs. 20000 to 40000 (124 individuals) and above 
Rs.40000 (93 individuals). The people who had been using skincare agents for the past three months were considered as "users".

Table 1. Statistics on the usage of skincare agents by inhabitants in Galle District, Sri Lanka

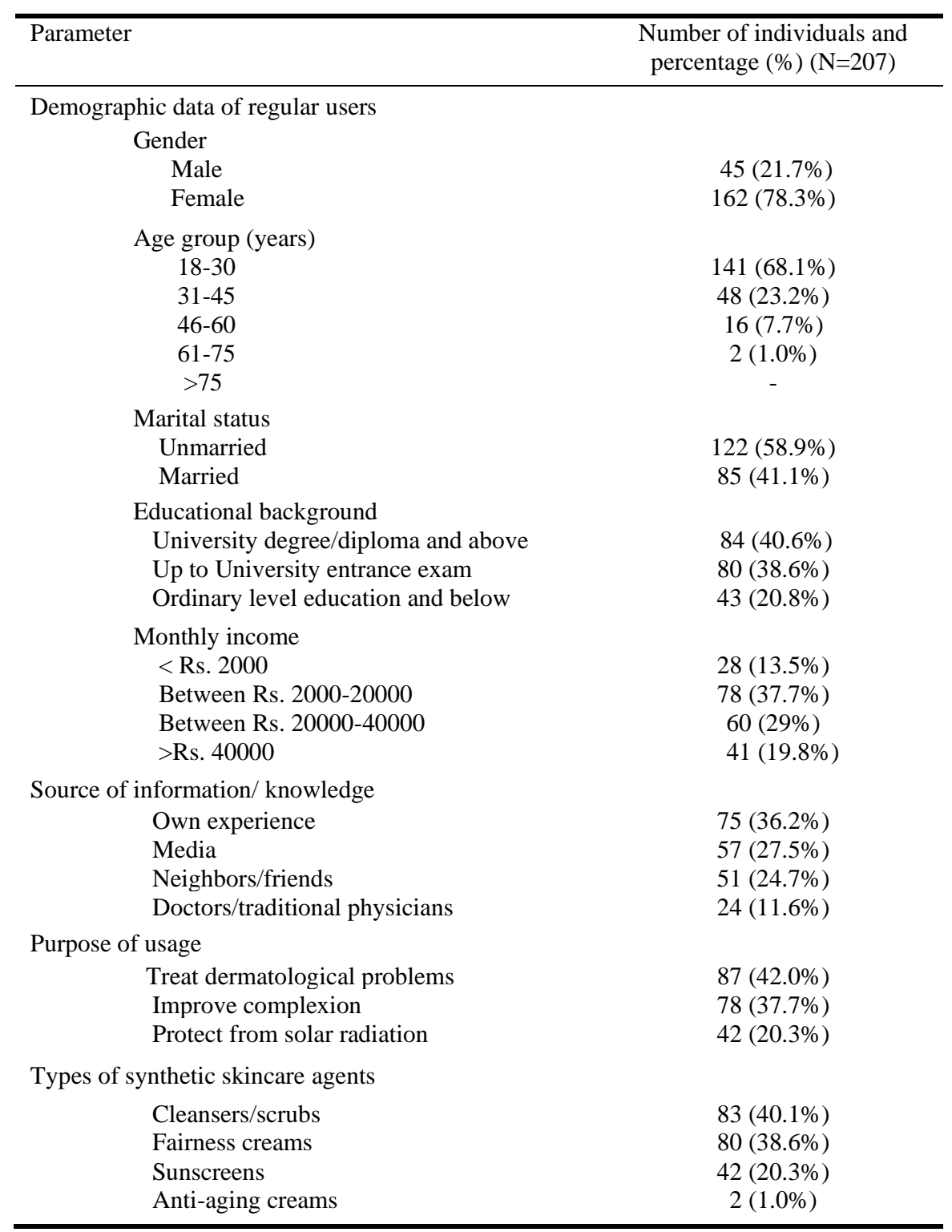

The study revealed that out of those 390 participants, 207 (53.1\%) were using skincare agents, whereas 183 individuals (46.9\%) were found to be non-users of such products. Among the regular users of the skincare agents, a majority were found to be females 
(78.4\%) at the age groups of 18-30 years. Both male and female users were with a good educational background either educated up to the university entrance examination or with a university degree/diploma. The majority, i.e. 141 individuals (68.1\%) claimed the usage of these products for five years. They have gained the knowledge/ information on skincare agents through their own experience, through the media, from neighbors/friends, or by doctors/traditional physicians. The usage was mainly for the purpose of treating dermatological problems like acne and wrinkles either with the recommendation of doctors or as self-medication. Apart from that, the other main purposes include improving complexion and to protect the skin from solar radiation. The statistics on the usage of skincare agents are summarized in Table 1.

Chi-square test was used to assess the association between demographic data and skincare product usage and, a statistically significant association was observed between demographic factors gender, age, marital status, employment status, and the usage of skincare products $(\mathrm{p}<0.001)$.

The study revealed that the synthetic skincare agents were much popular in the community $(58 \%, 120$ individuals) whereas $8.2 \%$ of the users, i.e. 17 individuals, were using only home-made herbal preparations while 70 persons (33.8\%) claimed the use of both synthetic and herbal products.

\subsection{Knowledge attitude and awareness on skincare products}

Among different categories of synthetic skincare agents mentioned by the users, cleansers/ scrubs were highly popular. The other types include fairness creams, sunscreens, and anti-aging agents. However, consumer awareness of different parameters of these products was not satisfactory. For example, only 100 (48.3\%), 48 (23.2\%), and $82(39.6 \%)$ individuals were knowledgeable on $\mathrm{pH}$, sun protection factor (SPF), and chemical composition of the product respectively. Further, only 136 persons $(65.7 \%)$ were attentive to the recommended quantity to be used per day. The majority of the participants, i.e. 155 persons $(74.8 \%)$, were satisfied with the effectiveness of these products and only 20 individuals $(9.7 \%)$ complained about noticeable sideeffects. Fifty-five percent of the users (114 individuals) preferred synthetic products as those were readily available in the market. A significant number of participants stated that the popularity of these products was the reason for their choice. However, only $9.4 \%$ believed that these synthetic products were more effective than herbal preparations. Most of the users of synthetic skincare agents (81.2\%) claimed that they would adopt herbal skincare therapeutics if proper scientific investigations were conducted to validate the efficacy of those products.

\subsection{Herbal skincare agent usage}

Among the users of the home-made herbal skincare preparations, the majority claimed that they choose these products due to their belief in the safety and low side effect profiles. A considerable number of participants stated that these preparations were 
found to be effective previously while the others mentioned that the availability of plant materials in their surroundings allowed them to prepare and use herbal formulations at a low cost. The survey led to the identification of 17 plant species that have been used in herbal skin care preparations (Table 2). Out of the plant species, Curcuma longa was the most cited species while Aloe vera was the second most cited species. Most of the plant species were grown in home gardens and commonly available.

Table 2: Plant species used in the home-made herbal skincare preparations (N: number of people who use the plant species; TA: Topical application).

\begin{tabular}{|c|c|c|c|c|c|}
\hline Plant Species & $\begin{array}{l}\text { Vernacular } \\
\text { name } \\
\text { (Sinhala) }\end{array}$ & Family & Plant part & $\begin{array}{l}\text { Mode of } \\
\text { preparation }\end{array}$ & $\mathrm{N}$ \\
\hline $\begin{array}{l}\text { Trigonella } \\
\text { foenum- } \\
\text { graecum }\end{array}$ & Ulu-hal & Fabaceae & Seeds & $\begin{array}{l}\text { Mixed with } \\
\text { coconut oil (TA) }\end{array}$ & 06 \\
\hline $\begin{array}{l}\text { Vetiveria } \\
\text { zizanioides }\end{array}$ & Savendara & Poaceae & Roots & $\begin{array}{l}\text { Powdered and } \\
\text { mixed with water } \\
\text { (TA) }\end{array}$ & 06 \\
\hline $\begin{array}{l}\text { Santalum } \\
\text { album }\end{array}$ & Sudu-hadun & Santalaceae & Bark & $\begin{array}{l}\text { Powdered and } \\
\text { mixed with lime } \\
\text { juice/water (TA) }\end{array}$ & 07 \\
\hline $\begin{array}{l}\text { Kokoona } \\
\text { zeylanica }\end{array}$ & Kokum & Celastraceae & Bark & $\begin{array}{l}\text { Mixed with lime } \\
\text { juice (TA) }\end{array}$ & 04 \\
\hline $\begin{array}{l}\text { Citrus } \\
\text { aurantifolia }\end{array}$ & Dehi & Rutaceae & Fruit & $\begin{array}{l}\text { Juice is mixed with } \\
\text { sugar/bee honey } \\
\text { (TA) }\end{array}$ & 07 \\
\hline $\begin{array}{l}\text { Curcuma } \\
\text { longa }\end{array}$ & Kaha & Zingiberaceae & Rhizome & $\begin{array}{l}\text { Ground and mixed } \\
\text { with yogurt/ eggs/ } \\
\text { coffee (TA) }\end{array}$ & 10 \\
\hline $\begin{array}{r}\text { Camellia } \\
\text { sinensis }\end{array}$ & Tea & Theaceae & Leaves & $\begin{array}{l}\text { Ground with water } \\
\text { (TA) }\end{array}$ & 02 \\
\hline $\begin{array}{l}\text { Azadirachta } \\
\text { indica }\end{array}$ & Kohomba & Meliaceae & Leaves & $\begin{array}{l}\text { Ground with } \\
\text { Curcuma (TA) }\end{array}$ & 05 \\
\hline Aloe vera & Komarika & Xanthorrhoeaceae & Leaves & $\begin{array}{l}\text { Extracted the gel/ } \\
\text { sap (TA) }\end{array}$ & 08 \\
\hline
\end{tabular}


Table 2. Continued

\begin{tabular}{|c|c|c|c|c|c|}
\hline Plant Species & $\begin{array}{l}\text { Vernacular } \\
\text { name } \\
\text { (Sinhala) }\end{array}$ & Family & Plant part & $\begin{array}{l}\text { Mode of } \\
\text { preparation }\end{array}$ & $\mathrm{N}$ \\
\hline $\begin{array}{l}\text { Persea } \\
\text { americana }\end{array}$ & Aligatapera & Lauraceae & Fruit & $\begin{array}{l}\text { Prepared a paste } \\
\text { (TA) }\end{array}$ & 07 \\
\hline $\begin{array}{l}\text { Cicer } \\
\text { arietinum }\end{array}$ & Kadala & Fabaceae & Seeds & $\begin{array}{l}\text { Ground with Lens } \\
\text { culinaris and water } \\
\text { (TA) }\end{array}$ & 05 \\
\hline $\begin{array}{l}\text { Cucumis } \\
\text { sativus }\end{array}$ & Pipinya & Cucurbitaceae & Fruit & $\begin{array}{l}\text { Cut into slices and } \\
\text { placed on the eyes }\end{array}$ & 06 \\
\hline Cassia alata & Eth-thora & Fabaceae & Leaves & $\begin{array}{l}\text { Ground with water } \\
\text { (TA) }\end{array}$ & 07 \\
\hline $\begin{array}{l}\text { Coscinium } \\
\text { fenestratum }\end{array}$ & Veniwel & Menispermaceae & Stem & $\begin{array}{l}\text { Powdered and } \\
\text { mixed with water } \\
\text { (TA) }\end{array}$ & 07 \\
\hline $\begin{array}{l}\text { Curcuma } \\
\text { aromatica }\end{array}$ & $\begin{array}{l}\text { Kasthuri } \\
\text { Kaha }\end{array}$ & Zingiberaceae & Rhizome & $\begin{array}{l}\text { Ground with lime } \\
\text { juice and water } \\
\text { (TA) }\end{array}$ & 04 \\
\hline $\begin{array}{l}\text { Aegle } \\
\text { marmelos }\end{array}$ & Beli & Rutaceae & Fruit & $\begin{array}{l}\text { Prepared a paste } \\
\text { (TA) }\end{array}$ & 01 \\
\hline $\begin{array}{l}\text { Punica } \\
\text { granatum }\end{array}$ & Delum & Punicaceae & Fruit & $\begin{array}{l}\text { Seeds are used to } \\
\text { make a drink }\end{array}$ & 04 \\
\hline
\end{tabular}

\section{Discussion}

This is the first in-depth scientific report on the practice, knowledge/ awareness, and attitudes on skincare product usage among Sri Lankans. The study revealed that the skincare agents were quite popular among the study population as more than $50 \%$ claimed the usage of such products. However, the use of skincare agents among males was low irrespective of their educational level. Even among females, these agents were more popular among unmarried women and after the marriage, it seems that their concern about maintaining healthy skin has reduced. Regarding the influence of the economic conditions on the usage of skincare products, the majority of respondents declared that this factor was not a determinant issue. The knowledge of different parameters in the skincare products such as $\mathrm{pH}, \mathrm{SPF}$ was rather poor and unfortunately, the majority were not aware of the chemical composition of the products they were using. Since Galle area receives high solar radiation throughout the year and many people are working for long hours under these conditions, the usage of skincare 
preparations would be an important strategy to prevent possible harmful effects of solar radiation. However, the number of individuals who routinely use sunscreens was considerably low. On the other hand, a substantial number of people had used skincare agents for the purpose of improving complexion and a similar trend was observed in studies conducted among women in Malaysia and Jordan which reported a prevalence rate of $60.6 \%$ and $60.7 \%$ respectively for the use of skin-lightening products (Rusmadi et al. 2015, Hamed et al. 2010).

Although the popularity of synthetic skincare products was higher than the homemade herbal preparations, the study revealed that the majority are ready to shift towards the herbal preparations, if their efficacy could be proven scientifically. This reflects the increasing demand of the society for natural preparations and would be great momentum for the researchers who are working on herbal cosmetics. These findings further support the observations of the ethnobotanical survey on the cosmetic use of indigenous plants in North Sri Lanka by Nirmalan (2017) that revealed the women of the study area prefer herbal cosmetics as they believe the effectiveness of herbs and low side effect profiles.

Many of the quoted species represented well-known medicinal plants in Sri Lanka and the Indian subcontinent, for example, the utility of Aloe vera as a moisturizer, Azadirachta indica as a skin cleaner and Curcuma longa as an enhancer of complexion (Gediya et al. 2011). The herbal formulations were prepared from various plant parts of a single plant, or multiple plants where some were administered along with lime juice, honey, coconut oil, yogurt, etc. Since Sri Lankan flora is rich in plant species with potential applicability in health care but still under-exploited, the utilization of such plant species after being duly studied would be a safe, efficacious, and costeffective alternative to the synthetic skincare products.

\section{Conclusions}

Skincare products were widely accepted by females in the study area and synthetic products were highly popular among them. However, most of the users were not concerned about the chemical composition, $\mathrm{pH}$, and SPF of the synthetic products and the effect of these products on the skin indicating that a mechanism to increase consumer awareness is essential. Furthermore, the study also indicated that the current trend is towards the herbal formulations and scientific validation of such material would pose an impact on the popularity of herbal skin care preparations.

\section{Acknowledgments}

The authors are grateful to the Department of Meteorology, Sri Lanka for providing solar radiation data. Drs. Anuruddha Mendis and Kaushlya Sammani are gratefully acknowledged for their support during the collection of data. Two anonymous reviewers are greatly acknowledged for their critical comments on the initial manuscript. 


\section{References}

Ahmad M, Khan MA, Zafar M. 2008. Traditional herbal cosmetics used by local women communities in district Attock of Northern Pakistan. Indian Journal of Traditional Knowledge 7(3): 421-424.

Department of Census and Statistics. 2017. http://www.statistics.gov.lk/pophousat/cph2011/Pages/ Activities / Reports/ Southern.pdf. Accessed 25th June 2017

Gediya SK, Mistry RB, Patel UK, Blessy M, Jain HN. 2011. Herbal Plants: Used as a cosmetics. Journal of Natural Product and Plant Resources 1: 24-32.

Gunapala AAS, Kumara NWD. 2015. Ayurveda for beauty cultural purpose- a review. Proceedings of 3rd International Conference on Ayurveda, Unani, Siddha and Traditional Medicine 188.

Hamed, SH, Tayyem R, Nimer N, AlKhatib HS. 2010. Skin-lightening practice among women living in Jordan: prevalence, determinants, and user's awareness. International Journal of Dermatology 49(4): 414-420.

Jayaweera DMA. 1982. Medicinal plants (Indigenous and exotic) used in Ceylon, Part 1-5. National Science Council, Sri Lanka.

Mahé A, Blanc L, Halna JM, Kéita S, Sanogo T, Bobin P. 1993. An epidemiologic survey on the cosmetic use of bleaching agents by the women of Bamako (Mali). Annales De Dermatologie Et De Venereologie 120(12): 870-873.

Nirmalan TE. 2017. Cosmetic Perspectives of Ethno-botany in Northern Part of Sri Lanka. Journal of Cosmetology \& Trichology 3:126.

Rusmadi SZ, Ismail SNS, Praveena SM. 2015. Preliminary study on the skin lightening practice and health symptoms among female students in Malaysia. Journal of Environmental and Public Health vol. 2015, Article ID 591790: 6 pages.

Rekha MB, Gokila K. 2015. A study on consumer awareness, attitude and preference towards herbal cosmetic products with special reference to Coimbatore city. International Journal of Interdisciplinary and Multidisciplinary Studies 2(4): 96-100.

Ribeiro AS, Estanqueiro M, Oliveira MB, Lobo JMS. 2001. Main benefits and applicability of plant extracts in skincare products. Cosmetics 2(2): 48-65.

Wijesundera DSA. 2004. Inventory, documentation and medicinal plant research in Sri Lanka. Medicinal Plant Research in Asia 1: 184-195. 